\title{
On challenging aspects of countering the international terrorism
}

\author{
Oleg Anatolyevich Stepanov ${ }^{{ }^{*}}$ and Evgeniya Nikolaevna Prokhorova ${ }^{2}$ \\ ${ }^{1}$ Institute of Legislation and Comparative Law under the Government of the Russian Federation, \\ Center for Criminal Legislation, Criminal and Procedure Legislation, Judicial Practice, Moscow, \\ Russia \\ ${ }^{2}$ Kaliningrad branch of the Saint Petersburg University of the Ministry of Internal Affairs of Russia, \\ Department of Criminal Procedure, Kaliningrad, Russia
}

\begin{abstract}
The problem of international terrorism has become one of the serious problems hindering the sustainable development of the global community. The tragic events in Moscow, Beslan, New York, Madrid, Monte Carlo, London, and Paris have clearly shown this. The prerequisite for the study is an increase in the spread of international terrorism and the associated new threats and risks for the world community. International terrorism has many forms of manifestation aimed at causing harm to various objects (on the ground, in the waters, in the air, on the Internet), including critical infrastructure facilities associated with the use of nuclear materials. Also, the second decade of the 21 st century was marked by hundreds of thousands of victims and millions of refugees associated with the consequences of terrorist activities on the territory of Syria, Iraq, and other states. The main objective of the study is to investigate socially significant scientific problems associated with countering this negative phenomenon. The result of the study is the introduction of the concept of "international security" into scientific circulation, which should be understood as the state of protection of subjects of international law from internal and external threats, based on the consideration of the interests of these subjects related to the leveling of dangerous manifestations that are global. At the same time, the authors emphasize the need to consider the development of the artificial intelligence sphere in the framework of countering the international terrorism threat. The results obtained in the study have not been previously published in literary sources and can serve as a guideline for further scientific research in the field of countering international terrorism.
\end{abstract}

Keywords: international terrorism, countering terrorism, financing of terrorism

\section{Introduction}

The presented study highlights issues related to the analysis of the use of law enforcement resources in the field of countering international terrorism. The field of activity related to the

\footnotetext{
* Corresponding author: o_stepanov28@mail.ru
} 
protection of natural human rights from international terrorist manifestations is the subject of a comprehensive study for the authors.

The article focuses on the theoretical understanding of the problem of countering international terrorism. The theoretical and methodological basis of the study was the work of such authors as Y.I. Avdeev, P.V. Agapov, Y.M. Antonyan, I.I. Artamonov, A.G. Volevodz, Y.S. Gorbunov, V.I. Grachev, V.V. Luneev, V.V. Merkuriev, A.V. Naumov, V.I. Popov, V.E. Petrishchev, S.A. Starostina, O.A. Stepanov, V.V. Ustinov, and other scientists and law enforcement specialists.

\section{Methods}

The research hypothesis is based on the need to develop new approaches to localizing international terrorist manifestations based on the use of all available resources.

Based on this, the goal and objectives of the study are determined by the need to develop an integrated approach in the field of countering international terrorism.

Achievement of this goal is associated with the solution of the following scientific and practical tasks:

- formulation and substantiation of the main provisions related to countering terrorism;

- identification of factors contributing to the spread of international terrorism;

- proposal of measures to improve law enforcement in this area.

The methodological basis of the research was made up of the methods of logic that allow considering the diverse ties in the field of countering international terrorism, as well as such empirical methods of knowledge as the analysis of legislation, the study of documents, the study of electronic information resources.

\section{$3 \quad$ Results and discussion}

The events of recent years reflect the severity of the international terrorist threat to the Russian Federation. And if 25 terrorist attacks were prevented on the territory of the Russian Federation in 2017 [1], then already 39 of them were prevented in 2019 [2].

Speaking with the annual report to the Federation Council on June 17, 2020, the Prosecutor General of the Russian Federation I.V. Krasnov drew attention to the continued high level of terrorist threats. "The number of terrorist attacks prevented increased by more than a third (38\%). They were identified in 24 regions; places of mass gathering of people were chosen as targets" [3].

One of the factors influencing the spread of international terrorism is the lack of proper coordination of actions along the procedural line of interaction between domestic law enforcement agencies and the intelligence services of foreign countries.

A striking example of this manifestation is the transfer of hundreds of mercenaries from the international terrorist organizations fighting in the Middle East to the area of the NagornoKarabakh incident [4]. For example, French President Emmanuel Macron said that Paris has "accurate information" about the participation of Syrian militants in the hostilities in Nagorno-Karabakh. According to him, more than 300 Syrian Islamists were transferred to the conflict zone through the Turkish Gaziantep [5].

It should be noted that it is important to consider the criminal legal means of countering terrorist activities in their unity and the interrelation of national and international factors.

In this regard, closer coordination between law enforcement structures at the international level is required, associated with the exchange of significant information. In this case, a clear positive example is an interaction of the Russian FSB with the US CIA on the prevention of large-scale terrorist attacks in the city of St. Petersburg in December 2017, as well as further 
development of the capabilities of the International Criminal Court (ICC), due to the introduction of a European arrest warrant, the suppression of the channel of financing of extremist organizations, and the formation of a list of terrorist organizations [6].

However, the possibility of attributing international terrorism to the jurisdiction of the ICC today encounters certain barriers. Thus, in 1994, the United States actively opposed the extension of the jurisdiction of the ICC to these crimes, referring to the fact that they are very successfully coping with the investigation and suppression of these crimes with their means and spend colossal amounts of money on this [7].

The objectively existing needs for coordinating the actions of states in the prevention, suppression, and punishment of crimes of a terrorist nature determine the intensification of the activities of specialized international organizations. So, at present, a set of measures is in place to prevent money laundering and terrorist financing, adopted only by Europol and Interpol.

Note that credit and credit card fraud "allow terrorists to receive significant financial resources in the form of donations and direct "tribute" from outright racketeering, "launder" the funds received to create their economy, which, according to their plan, is designed to become the basis of the future "Great Caliphate of a single Islamic state" [8]. Therefore, as never before, the question of finding a universal basis for countering illegal and unlawful transactions has been updated [9]. "Cryptoeconomics is a global phenomenon and any crossborder transfer of currency values should be regulated in the same framework around the world" [10].

Although the financing of terrorism is an international crime, some doctrinal questions nevertheless arise in connection with holding persons who have transferred their funds to terrorists liable. We are talking about the relatives of those persons who are held hostage by terrorists demanding a ransom. On the one hand, transferring the required amount of money or, say, bitcoins, in many countries will be a crime, and the relatives themselves will have to bear criminal responsibility for such activities. On the other hand, the approach of the United States is interesting, where such a transaction is not considered a crime and no one brings relatives to justice [11].

In this regard, it should be noted that on June 15, 2017, the UN General Assembly Resolution 71/291 "Strengthening the capability of the United Nations system to assist the Member States in implementing the United Nations Global Counter-Terrorism Strategy" was adopted and a UN structural unit - Office of Counter-Terrorism - was established. This unit is entrusted with the strategic leadership of the anti-terrorism activities of the United Nations.

Taking this into account, it would be quite timely to introduce the definition of "international security" into circulation. According to B. Buzan, international security relates to the sphere of "ensuring survival, within which it is lawful to use emergency measures to protect against threats of a certain reference object" [12].

Various meanings of the term "reference" are given in the works of researchers [13, 14], namely, acting as a fact, events referred to in confirmation of some ideas and serving as a source of these ideas, a role model, and also, as a group of people with which an individual identifies himself and whose spiritual (moral) values he fully shares.

The key reference object in the field of international security is the person himself, whose protection takes place, among other things, through the adoption of armed measures aimed at strengthening state borders; prevention of violence, respect for human rights, and sustainable development [15].

Considering the above, in our opinion, international security is a state of protection of subjects of international law from internal and external threats, based on taking into account the interests of these subjects related to the leveling of global dangerous manifestations.

This interpretation presupposes the use of new organizational approaches to localizing the activities of international terrorists with the participation of suicide bombers, and the so- 
called "sleeping" cells of the IS, which are a reserve that can at any time fulfill the tasks of its curators upon a specific signal.

All of the above deserves the closest attention of legal scholars, who are called upon to take into account the need to counter the threat of international terrorism in the context of the development of the artificial intelligence sphere [16].

Considering this circumstance, the problem of cyberterrorism, which has been considered in the scientific works of several authors in the Russian legal literature, is of particular relevance. At the same time, the definition, signs, and specific characteristics of cyberterrorism are poorly developed. For example, some experts consider cyberterrorism to be a set of unlawful actions associated with attempts on the life of people, with threats of reprisals, destructive actions to material objects, distortion of objective information, or several other actions that contribute to the fear-mongering and tension fomenting in society to gain an advantage in solving political, economic or social tasks [17].

Golubev understands cyberterrorism as a deliberate attack on information processed by a computer, a computer system, or a network that poses a danger to the life and health of people or other grave consequences if such actions were committed with the aim of violating public safety, intimidating the population or provoking a military conflict [18].

Pobegailo defines cyberterrorism as an impact on decision-making by state authorities, local governments, or international organizations associated with intimidation of the population and (or) violent actions committed through the illegal use of information and communication technologies [19].

Other authors define cyberterrorism based on the impact of attacks, referring to attacks on computers that cause damage sufficient to be compared to a traditional act of terrorism, even if the cyber-attack was initiated with no political motivation [20].

In our opinion, cyberterrorism can be understood as a phenomenon associated with the actions of a person or a group of persons aimed at intimidating people, putting pressure on governments to create an atmosphere of fear in society, imposing a certain line of behavior on them, or causing significant harm through the use of information and electronic networks and (or) artificial intelligence systems [21].

Effective countering cyberterrorism requires the use of computer technology while investigating cyberterrorism. To be one step ahead of cyberterrorists requires special attention during the training of relevant law enforcement specialists [22].

\section{Conclusion}

The conclusions formulated by the authors not only develop the theoretical and practical aspects of countering international terrorism but can also serve as a guideline for preventing negative factors associated with the considered sphere of public relations in the context of the intensive development of digital technologies. This circumstance determines the spread of issues studied by the authors.

\section{References}

1. V Rossii v 2017 godu predotvrashcheno 25 teraktov [In 2017, 25 terrorist attacks were prevented in Russia] Accessed on: March 22, 2021. [Online]. Available: http://tass.ru/proisshestviya/4993950

2. S nachala 2019 goda $v$ Rossii predotvratili 39 teraktov [Since the beginning of 2019 , 39 terrorist attacks have been prevented in Russia] Accessed on: March 22, 2021.

[Online]. Available: https://tass.ru/politika/7006062 
3. Chislo predotvrashchennykh teraktov v Rossii za god vyroslo na tret' [The number of prevented terrorist attacks in Russia has grown by a third over the year] Accessed on: March 22, 2021. [Online]. Available: https://iz.ru/1024656/2020-06-17/chislopredotvrashchennykh-teraktov-v-rossii-za-god-vyroslo-na-tret

4. Siriiskie boeviki v uzhase ot armyanskikh snaiperov [Syrian militants are terrified by Armenian snipers] Accessed on: March 22, 2021. [Online]. Available: https://ru.armeniasputnik.am/karabah/20201015/24916830/Takoe-videli-tolko-vfilmakh-siriyskie-boeviki-v-uzhase-ot-armyanskikh-snayperov.html

5. WP: v Nagornom Karabakhe ubity bolee 50 siriiskikh naemnikov [WP: Over 50 Syrian mercenaries killed in Nagorno-Karabakh] Accessed on: March 22, 2021. [Online]. Available:

https://www.kommersant.ru/doc/4531133?utm_source=yxnews\&utm_medium=deskto p\#id1960278

6. D.A. Pechegin, Sostyazatel'naya i rozysknaya modeli sudoproizvodstva v Mezhdunarodnom ugolovnom sude [Adversarial and investigative models of legal proceedings in the International Criminal Court] (Moscow, Jurlitinform, 2017).

7. J. Vyver, Emory Int. Law Rev. 24(2), 527-547 (2010)

8. S.I. Grachev, Kontrterrorizm: organizatsionnye, pravovye, finansovye aspekty i voprosy profilaktiki [Counterterrorism: organizational, legal, financial aspects and issues of prevention], in O.A. Kolobov (ed.) (Nizhny Novgorod, 2010)

9. K. McConnell, SCRIBD, 22, 1-65 (2018)

10. T. Mandjee, J. Bus. \& Secur. Law 15(2), 158-218 (2015)

11. Y.V. Truntsevsky, Vynuzhdennoe posobnichestvo terroristicheskoi organizatsii kak obstoyatelstvo, isklyuchayushchee prestupnost deyaniya [Forced aiding of a terrorist organization as a circumstance excluding the criminality of an act], in Proc. XV Int. Sc. and Pract. Conf. "Criminal law: development strategy in the XXI century", Moscow, Russia (2018)

12. B. Buzan, Oslo Workshop Papers, 1-25 (2006)

13. T.V. Verbitskaya, Int. Pub. and Priv. Law 4, 21-24 (2017)

14. J. Ruban, Dictionnaire encyclopédique sur pédagogique et psychologie (Paris, 2013)

15. S. Tadjbakhsh, A. Chenoy, Human Security: Concepts and Implications (Routledge, New York, 2007)

16. I.V. Kotenko, R.M. Yusupov, Inf. Sec. INCIDE 2, 74-79 (2009)

17. V.A. Vasenin, Informatsionnaya bezopasnost' i komp'yuternyi terrorizm [Information security and computer terrorism]. Accessed on: March 22, 2021. [Online]. Available: http://www.crime-research.ru

18. V.A. Golubev, Kiberterrorizm - ugroza natsional'noi bezopasnosti [Cyber terrorism is a threat to national security]. Accessed on: March 22, 2021. [Online]. Available: http://www.crive-research.ru

19. A.E. Pobegailo, Kiberprestupnost: ucheb. posobie [Cybercrime: workbook] (Academy of the General Prosecutor's Office of RF, Moscow, 2014)

20. Congressional Research Service Reports on Terrorism. Accessed on: March 22, 2021. [Online]. Available: https://fas.org/sgp/crs/terror/index.html

21. O.A. Stepanov, Protivodeistvie kiberterrorizmu v tsifrovuyu epokhu [Countering cyberterrorism in the digital age] (Urait Publishing House, Moscow, 2020)

22. V. Akimov, Kriminalisticheskaya osobennost' kiberprestuplenii [Forensic feature of cybercrimes]. Accessed on: March 22, 2021. [Online]. Available: http://www.crimeresearch.ru/articles/cyber1299 